\title{
Determination of the Knowledge Management Strategy (A Case: Iran Alloy Steel Company)
}

\author{
Ali Nadizadeh, Ali Sabzevari Zadeh and Rashed Sahraeian
}

\begin{abstract}
In the competitive world, companies have realized that knowledge can only create competitive advantage and sustain them among other companies. Moreover, the appropriate management of knowledge is necessary for companies to achieve competitive advantage. On the other hand, selecting the right knowledge management strategy can be the first step of reaching to this advantage. In this paper, knowledge management strategy (KM-ST) is developed for Iran Alloy Steel Company (IASCO) as a real case. To determine the KM-ST, the Tiwana's model is selected and adopted for IASCO. The model shows that the business strategy and knowledge management strategy should be alignment with together to create a great synergy. This study supports managers to apply the model for determination of proper KM-ST in other companies.
\end{abstract}

Index Terms - Codification, Knowledge, Knowledge management strategy, Personalization.

\section{INTRODUCTION}

Nowadays knowledge has become the most important factor in companies as a competitive advantage. Companies consider it as their intangible assets that unlike physical assets can increase regularly by using it [1]. In the past till now knowledge has been linked with terms such as data, information, intelligence, skill, experience, expertise, ideas, intuition, or insight, which all depend on the context in which the words are used [2]. There are two types of knowledge assets. One kind of knowledge is explicit or formal assets like copyrights, patents, templates, publications, reports, archives, etc. Another kind is tacit or informal assets that are rooted in human experience and include personal belief, perspective, and values. The process of identification and leverage of organizational knowledge assets that deliver business advantage to the organization and its customer is related to field of knowledge management [3]. Knowledge management is about developing, sharing and applying knowledge within the firm to gain a competitive advantage. Its popularity has increased rapidly in the last decade, and it has become a central topic of management philosophy [4].

If the knowledge is to be successfully managed, there must be a high relation between the company's business strategy and its knowledge management strategy [5]. This indicates that knowledge management strategy should be aligned with the strategy of the company. Companies usually use SWOT

Manuscript received September 9, 2011; revised November 10, 2011

A. Nadizadeh is with the Industrial Engineering Department, Faculty of Engineering, Yazd University, Yazd, Iran (e-mail: alinadizadeh1@) gmail.com).

A. Sabzevari Zadeh and R. Sahraeian are with the Industrial Engineering Department, Faculty of Engineering, Shahed University, Tehran, Iran (e-mail: alisabzevary@gmail.com; rdsni@yahoo.com). framework, which put forward by Montgomery and Porter [6], to determine the business strategy for their organization. SWOT analysis involves an assessment of the company's strengths and weaknesses relative to the opportunities and threats, brought about by the environment in which the company operates. The objective is to sustain the company's strengths, mitigate its weaknesses, avoid threats and grab opportunities [5]. On the other hand, some different kinds of models for determining the appropriate knowledge management strategy are developed in literature that will be discussed in next section.

This paper describes a method to determine the knowledge management strategy (KM-ST) for companies. Iran Alloy Steel Company (IASCO), a big alloy steel producers in Iran, is selected as a real case for establishing a KM-ST model. This study can help other companies to apply the proposed model. In this work, the Tiwana's model is used for determining KM-ST of IASCO. The remainder of the paper is organized as follows; Section 2 reviews the literature briefly on KM-ST. Details of the Tiwana's model with case study are described in Section 3. Finally, the discussion and conclusion remarks are presented in Section 4.

\section{II.LITERATURE REVIEW ON KNOWLEDGE MANAGEMENT STRATEGY}

Companies have realized that only knowledge, as intangible assets, can sustain them among other companies and create competitive advantage for them. On the other hand, Knowledge management (KM) has been widely used recently by firms and organizations in order to make decisions more efficiently, product innovation, productivity and profits [4]. The growing importance of knowledge as a critical resource has encouraged managers to pay greater attention to the knowledge management strategy (KM-ST) of their firms. Bierly and Chakrabarti introduced the concept of KM-ST for the first time [7]. They defined KM-ST as the collective response of managers to the strategic learning needs of the firm. Based on some criteria such as internal and/or external learning, radical and/or incremental learning, slow and/or fast learning and broad and/or narrow knowledge base, they identified several distinct generic knowledge strategies among the pharmaceutical firms such as exploiters, explorers, loners and innovators [8]. Appropriate KM-ST is important to ensure that the alignment of organizational process, culture, and the KM-related Information Technology (IT) deployment produce effective knowledge creation, sharing, and utilization [9]. Some of the related works that proposed KM-ST models is reviewed as follow:

Hansen et al. argue that there are two strategies for managing knowledge: codification and personalization 
strategy [10]. The codification strategy intent to codify knowledge and its goal is transforming tacit knowledge to explicit knowledge. This strategy transforms knowledge to formal format that can be stored in database to be accessible and useable for everyone in company. Such companies invest heavily in IT for projects like intranets, data warehousing and data mining, knowledge mapping (identifying where the knowledge is located in the firm) and electronic libraries. Personalization strategy refers to personal development of tacit knowledge that is based on insights, intuition and personal skills for solving complex problems. In personalization strategy, knowledge is mainly shared through direct person-to-person contacts. The stress of personalization strategy is on flexibility, investment in learning and the creation of new capabilities [4]. It points that codification is closely related to exploitative learning, while personalization and explorative learning are closely related. Explorative learning is associated with complex search, basic research, innovation, risk-taking and more relaxed controls but exploitative learning tends to refine existing capabilities and technologies, forcing through standardization and reutilization, and is risk-averse [11].

Edvardsson presented an integrated model for selecting the appropriate KM-ST [4]. He linked human resource management (HRM) to KM and considered two KM-STs; exploitative and explorative strategy. He stated that exploitative strategy put greater emphasis on knowledge storage, technical skills as well as distributing explicit knowledge via IT solutions. This increases the risk that firms adopting such strategy are locked into past design and to be unable to reach for future applications. On the other hand, explorative strategy places greater weight on knowledge creation as well as on human interaction to transfer tacit knowledge and use knowledge to increase innovation and new learning. Firms adopting such strategy tend to lack structure and processes to utilize the innovations into competitive advantages. In mentioned publication, to determine the proper KM-ST some HRM practices such as recruitment, training, performance management and reward are used. Gloet and Berrell stated that there is a tendency for the implementation of an exploitative strategy, as people feel at ease in such an environment. It also offers more structure and precision to deal with explicit rather than tacit knowledge [12].

Tiwana argues on two expansive KM-STs: codification and personalization [5]. He states that both approaches are required in the right balance in firms and both strategies must be present in the knowledge orientation of the firm, but not with equal weightage. If a company decides to use codification as its primary strategy, it should direct, for example, 80 percent of its efforts toward codification and the remaining 20 percent toward personalization. He mentions that the codification strategy is more focused on technology that enables storage, indexing, retrieval, and reuse. This strategy is more appropriate for companies that have to deal with similar problems and decisions over and over. On the other hand, the personalization strategy is always focused on connecting knowledge workers and is more appropriate for companies that face one-off and unique problems that depend more on tacit knowledge and expertise than codified knowledge. In Table I, a review of KM-ST is presented. This table indicates the comparison between the different KM-ST based on some researchers' ideas.

In this paper, a KM-ST that is based on Tiwana's model is developed. To implement the mentioned model, IASCO is selected as a case study that can be expanded for other companies. In next section, according to the steps of Tiwana's model, the KM-ST for the IASCO is determined.

TABLE I: THE COMPARISON BETWEEN THE DIFFERENT KM-ST

\begin{tabular}{|c|c|c|c|}
\hline Researcher & $\begin{array}{l}\text { KM strategy } \\
\text { categories }\end{array}$ & $\begin{array}{l}\text { Suggested } \\
\text { KM strategy }\end{array}$ & $\begin{array}{l}\text { Researcher } \\
\text { method }\end{array}$ \\
\hline $\begin{array}{c}\text { Bierly and } \\
\text { Chakrbarti } \\
{[7]}\end{array}$ & $\begin{array}{l}\text { Loner; exploiter; } \\
\text { explorer; innovator }\end{array}$ & $\begin{array}{l}\text { Innovator or } \\
\text { explorer }\end{array}$ & Empirical \\
\hline Zack [13] & $\begin{array}{c}\text { Conservative; } \\
\text { aggressive }\end{array}$ & Aggressive & Conceptual \\
\hline $\begin{array}{c}\text { Hansen et al. } \\
\text { [10] and } \\
\text { Tiwana [5] }\end{array}$ & $\begin{array}{l}\text { Codification; } \\
\text { personalization }\end{array}$ & 80-20 split & Conceptual \\
\hline $\begin{array}{c}\text { Swan et al. } \\
{[14]}\end{array}$ & $\begin{array}{l}\text { Cognitive; } \\
\text { community }\end{array}$ & Community & Conceptual \\
\hline $\begin{array}{l}\text { Schulz and } \\
\text { Jobe [15] }\end{array}$ & $\begin{array}{c}\text { Codification; } \\
\text { tacitness; focused; } \\
\text { unfocused }\end{array}$ & Focused & Empirical \\
\hline $\begin{array}{l}\text { Gloet and } \\
\text { Berrell [12] }\end{array}$ & $\begin{array}{c}\text { Exploitative; } \\
\text { explorative; HRM } \\
\text { strategies }\end{array}$ & $\begin{array}{c}\text { Integrate HRM } \\
\text { strategies into } \\
\text { KM-ST. }\end{array}$ & Empirical \\
\hline $\begin{array}{l}\text { Choi and Lee } \\
{[16]}\end{array}$ & $\begin{array}{c}\text { Passive; } \\
\text { system-oriented; } \\
\text { human-oriented; } \\
\text { dynamic }\end{array}$ & Dynamic & Empirical \\
\hline Keskin [17] & $\begin{array}{l}\text { Explicit-oriented; } \\
\text { tacit-oriented }\end{array}$ & Explicit & Empirical \\
\hline Pai [18] & $\begin{array}{c}\text { Discoverer; } \\
\text { external learner; } \\
\text { internal } \\
\text { exploiter; overall } \\
\text { creationist }\end{array}$ & $\begin{array}{l}\text { Internal } \\
\text { exploiter }\end{array}$ & Empirical \\
\hline $\begin{array}{c}\text { Edvardsson } \\
{[4]}\end{array}$ & $\begin{array}{c}\text { Exploitative; } \\
\text { explorative; HRM } \\
\text { strategies }\end{array}$ & $\begin{array}{c}\text { Integrate HRM } \\
\text { strategies into } \\
\text { KM-ST. }\end{array}$ & Conceptual \\
\hline Choi et al. [9] & $\begin{array}{l}\text { External-oriented; } \\
\text { internal-oriented. }\end{array}$ & $\begin{array}{c}\text { Integrating } \\
\text { explicit-oriente } \\
\text { d with } \\
\text { tacit-oriented. }\end{array}$ & Empirical \\
\hline
\end{tabular}

III. KM-ST FOR THE IASCO BY TIWANA'S MODEL

To implement a successful KM-project in any firms, aligning KM-ST with business strategy is necessary. Tiwana stated most of company that have had a fair degree in KM-project have more focused on developing new IT applications for supporting digital capture, storage, retrieval, and distribution of an organization's explicitly documented knowledge [5]. Moreover, he argues that an effective KM-ST is not simply a technology strategy but a well-balanced mix of technology, cultural change, new reward systems, and business focus that is perfectly in step with the company's business strategy. Technical and organizational initiatives, when aligned and integrated, can provide a comprehensive infrastructure to support KM processes. The process of 
creating a well-articulated link between business strategy and knowledge strategy is summarized in Fig. 1. This model is based on a synthesis of suggestions by Zack [13] and Hansen et al. [10] that is the same of Tiwana's model. According to this process, some important steps of model are explained on IASCO at follow:

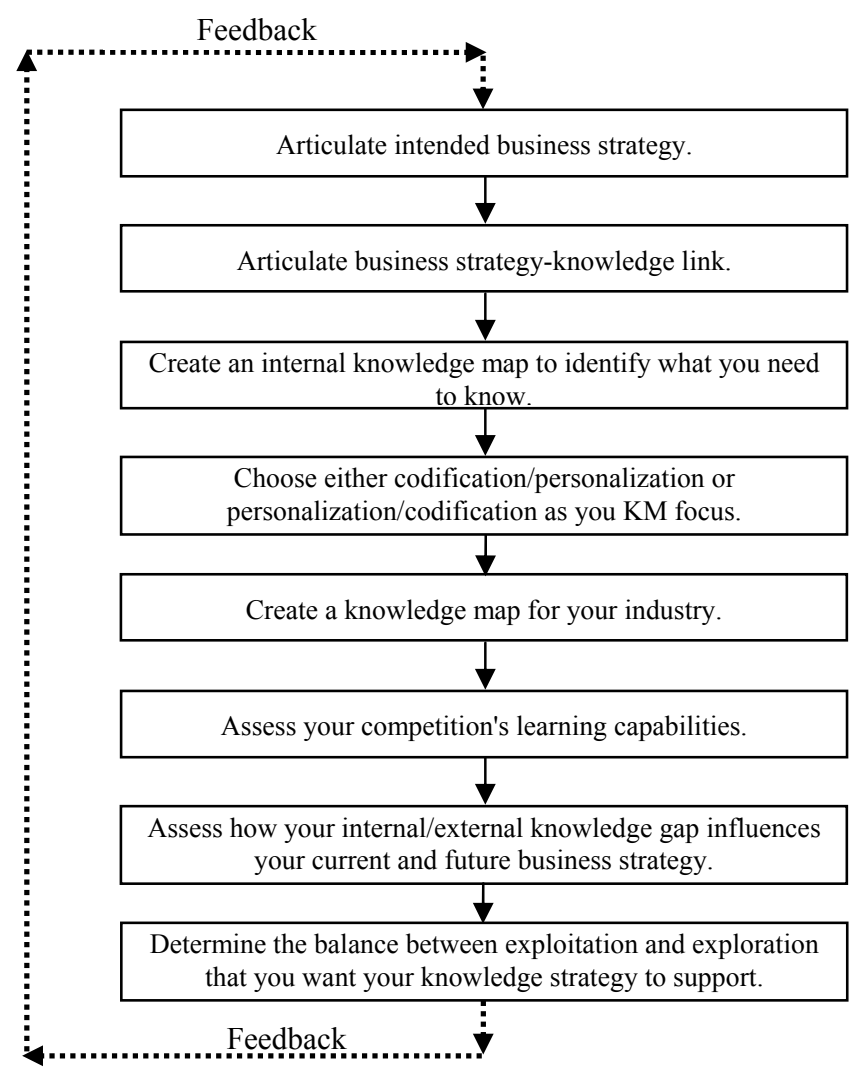

Fig. 1. The process of articulating the link between business and knowledge strategy, based on Tiwana's model

\section{A. Articulate intended business strategy}

Strategy is defined as the determination of the basic goals and objectives of an enterprise and the adoption of courses of action and the allocation of resources necessary for carrying out these goals [19]. A simple framework for generating strategic alternatives from a situation analysis is SWOT analysis. SWOT, that is an abbreviation for Strengths, Weakness, Opportunities, and Threats, provides the foundation for realization of the desired alignment of organizational variables or issues. By listing favorable and unfavorable internal and external issues in the four quadrants of a SWOT analysis grid, planners can better understand how strengths can be leveraged to realize new opportunities and understand how weaknesses can slow progress or magnify organizational threats. In addition, it is possible to postulate ways to overcome threats and weaknesses [20]. SWOT analysis can provide the key to aligning business strategy and KM-ST.

In IASCO, after analyzing the SWOT framework, the appropriate strategy is selected. This strategy is adopted for a five-year period. The basic strategic goals of the IASCO are shown as follow:

1) Acquiring of the superior business position and established brand of IASCO in the national level and Middle East region in field of alloy steels.

2) Focus on supply domestic demands for a variety grade of steel and special alloy parallel to enhance export products.

3) Production capacity expansion, technology development on the supply chain of special and alloy steels.

4) Improve performance indicators with emphasis on four central features: "World-class competitive products", "Delivery", "Technical Services" and "supply of a variety of products".

5) Emphasis on learning and knowledge-based company and promotion of efficient human resources.

6) Satisfaction of all stakeholders of company beside of observance of the social interests.

To analyze the gap between the current status of IASCO and what the organization wants to reach in future, each of the above strategic goals in each year will be targeted. Defining of the indicators for different units in company, performance units in achieving the strategic goals is measured in different periods.

\section{B. Articulate business strategy-knowledge link}

To articulate the strategy-knowledge link, a company must explicate its strategic intent, identify knowledge required to actually execute that strategic choice. The strategic choices that the company makes regarding technology, markets, products, services, and processes have a direct impact on the knowledge, skills, and competencies that it needs to compete in its intended markets [5]. Later, the links into actionable goals will be translated. For the IASCO, the required knowledge, which is related to the business strategic goals, is shown in Table II. First column of Table II indicates the items of strategic goals have already been cleared in previous section. Second column shows the targets associated with the strategic goals. The required knowledge for each strategic goal, which IASCO must reach to it in future, is shown in third column. Indices associated with the required knowledge to achieve strategic goals are targeted in forth column.

In Fig. 2, the knowledge status of IASCO is analyzed in the two situations. The former situation is the current position of company that is now faced with it and the latter one is the future position of company that would be achieved it during the planning horizon. The gap between what is the company doing and what it should be done represents its strategic gap as illustrated by Fig. 2. Similarly, the company's knowledge gap is represented by what the company should know and what it knows in order to support the competitive position that it has adopted. These two gaps must align and must feed into each other to bridge existing gaps. The company must choose the right KM-ST to manage the knowledge and strategic gap. KM-ST must address how the company's knowledge gaps in identified critical processes are best bridged [5].

As pointed before; Fig. 2 shows the strategic and knowledge gap of IASCO and link between knowledge and strategy in two situations. The bottom of Fig. 2 indicates the current status of the IASCO, in terms of the status of knowledge and business strategy objectives. The status of knowledge and business strategy goals that IASCO must achieve in future is shown in the top of Fig. 2. Note that, in this figure, targeted values of the knowledge and strategy goals in each position are given. The link between knowledge and strategy indicates that Knowledge can drive strategy and 
strategy can drive knowledge management, too ([5], pp. 162).

TABLE II: THE BUSINESS STRATEGY AND AsSOCIATED KNOWLEDGE WITH TARGETS

\begin{tabular}{|c|c|c|c|c|}
\hline No. & Strategic goals & Target (Related strategic goals) & Required knowledge & $\begin{array}{c}\text { Target (Related Knowledge } \\
\text { goals) }\end{array}$ \\
\hline 1 & $\begin{array}{l}\text { Superior business position } \\
\text { and established brand of } \\
\text { IASCO. }\end{array}$ & $\begin{array}{l}\text { Being IASCO within the top three } \\
\text { internal companies and the top eight } \\
\text { companies in the Middle East in terms } \\
\text { of producing alloy steels. }\end{array}$ & $\begin{array}{l}\text { Recognition of the status commercial } \\
\text { competitors such as: their marketing, } \\
\text { variety and quality of product, How to } \\
\text { deal with customers, services after sale } \\
\text { and etc. to earn their place. }\end{array}$ & $\begin{array}{l}\text { Mature recognition of top twenty } \\
\text { internal and external companies. }\end{array}$ \\
\hline 2 & $\begin{array}{l}\text { Supply domestic demands } \\
\text { in different grades. }\end{array}$ & $\begin{array}{c}\text { Supply alloy steels demands of } \\
80 \% \text { of customers. }\end{array}$ & $\begin{array}{l}\text { Identification and awareness of customer } \\
\text { needs and preferences. }\end{array}$ & $\begin{array}{l}\text { Mature knowledge of alloy steels } \\
\text { demands of } 85 \% \text { of customers. }\end{array}$ \\
\hline 3 & $\begin{array}{c}\text { Production capacity } \\
\text { expansion and technology } \\
\text { development. }\end{array}$ & $\begin{array}{c}\text { Produce } 360 \text { thousand tons per year in } \\
\text { IASCO }\end{array}$ & $\begin{array}{c}\text { Be familiar with new equipment and } \\
\text { updated casting lines and how to expand } \\
\text { the capacity of casting lines equipment } \\
\text { and furnaces. }\end{array}$ & $\begin{array}{l}\text { Knowing how to expand } \\
\text { production capacity ( } 75 \% \text { of } \\
\text { casting lines equipment and } \\
\text { furnaces). }\end{array}$ \\
\hline 4 & $\begin{array}{l}\text { Improve performance } \\
\text { indicators: World-class } \\
\text { competitive products, } \\
\text { Delivery, Technical } \\
\text { Services and supply a } \\
\text { variety of products. }\end{array}$ & $\begin{array}{c}\text { Producing } 15 \text { new grade alloy steels. } \\
\text { Consulting services ( } 20 \% \text { growth). } \\
\text { Reducing the delivery time ( } 10 \% \\
\text { growth). }\end{array}$ & $\begin{array}{l}\text { Acquiring the technical knowledge of } \\
\text { production of alloy steels in the new } \\
\text { grades. Enhance the production quality of } \\
\text { alloy steels using the new methods. To } \\
\text { minimize production time and delivery } \\
\text { orders by using efficient methods }\end{array}$ & $\begin{array}{l}\text { Acquiring the technical knowledge } \\
\text { of production of } 20 \text { new types of } \\
\text { grid alloys. }\end{array}$ \\
\hline 5 & $\begin{array}{l}\text { Emphasis on } \\
\text { knowledge-based and } \\
\text { learning company with } \\
\text { promotion of efficient } \\
\text { human resources. }\end{array}$ & $\begin{array}{l}\text { The growth of technical knowledge of } \\
\text { staffs in both practice and test ( } 20 \% \\
\text { growth). }\end{array}$ & $\begin{array}{l}\text { Keep the knowledge records of } \\
\text { employees and the organization to reuse } \\
\text { them in new situations. Register the new } \\
\text { patents. Increase the learning level of } \\
\text { staff with training them in different fields. }\end{array}$ & $\begin{array}{l}\text { Using guidelines and databases for } \\
70 \% \text { of employees to do routine } \\
\text { work. Number of new instructions } \\
\text { and patents ( } 20 \% \text { growth). } \\
\text { Employees participate in } \\
\text { workshops ( } 20 \% \text { growth). }\end{array}$ \\
\hline 6 & $\begin{array}{c}\text { Satisfaction of all } \\
\text { stakeholders of company. }\end{array}$ & $\begin{array}{l}\text { Stakeholder satisfaction rates rise } \\
\text { through the poll ( } 20 \% \text { growth). }\end{array}$ & $\begin{array}{l}\text { Identify needs and interests of } \\
\text { employees, shareholders, suppliers and } \\
\text { customers and trying to resolve their } \\
\text { needs. }\end{array}$ & $\begin{array}{l}\text { Awareness of the needs and } \\
\text { preferences and help } 80 \% \text { of } \\
\text { stakeholders to resolve their } \\
\text { problems. }\end{array}$ \\
\hline
\end{tabular}

\section{What the IASCO must know:}

- Awareness and applying useful knowledge of top 20 internal and external companies in terms of marketing, variety of product, customer's information and etc.

- Awareness of alloy steels demands of $85 \%$ of customers.

- Knowing how to expand production capacity $(75 \%$ of casting lines equipment and furnaces).

- Acquiring the technical knowledge of production of 20 new types of grid steel alloys.

- Using guidelines and databases for $70 \%$ of employees to do routine work. Number of new instructions and patents ( $20 \%$ growth). Staffs participate in workshops (20\% growth).

- Awareness of the needs and preferences and help $80 \%$ of stakeholders to resolve their problems.

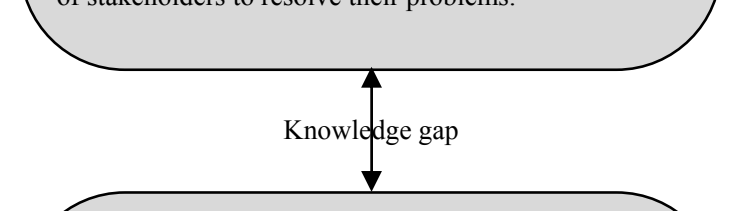

What the IASCO know:

- Awareness and using useful knowledge of top 12 internal and external companies in terms of marketing, variety of product, sales and purchase data, customers and etc.

- Awareness of alloy steels needs of $65 \%$ of customers.

- Knowing how to increase production capacity of equipment ( $50 \%$ of equipment).

- knowing the technical knowledge of production of 200 types of grid steel alloys.

- Using guidelines and databases for $40 \%$ of employees to do routine work. Number of instructions and patents are 765 . Staffs participate rate in workshops is $55 \%$.

- Awareness of the needs and preferences and help $60 \%$ of stakeholders to resolve their problems.

\section{What the IASCO must do:}

- Being IASCO within the top three internal companies and the top eight companies in the Middle East in terms of producing alloy steels.

- Supply alloy steels demands of $80 \%$ of customers.

- Produce 360 thousand tons per year in IASCO.

- Producing 15 new grade alloy steels. Consulting services (20\% growth). Reducing the delivery time (10\% growth).

- The growth of technical knowledge of staffs in both practice and test (20\% growth).

- Stakeholder satisfaction rates rise through the poll $(20 \%$ growth).
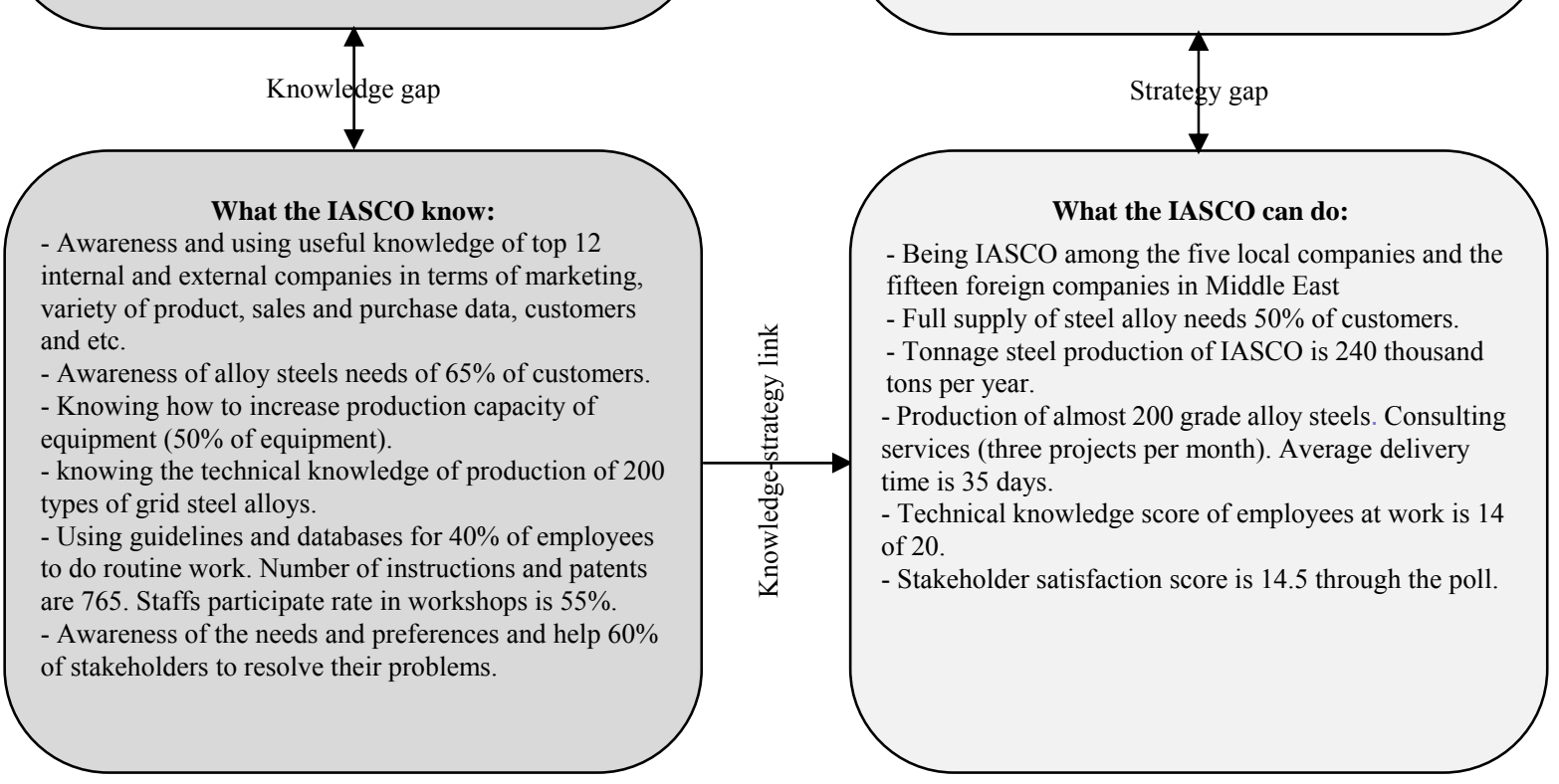

Fig. 2. Strategic and knowledge gap of IASCO and link between them 


\section{Create an internal knowledge map to identify what you need to know}

Creating an internal knowledge map, the company can identify what level of knowledge uses. Tiwana has categorized knowledge into three classifications as follow [5]:

1) Core knowledge: Core knowledge is the basic level of knowledge required just to play the game. This is the type of knowledge that creates a barrier for entry of new companies. Since this level of knowledge is expected of all competitors, the company must have it even though it will provide the company with no advantage that distinguishes it from its competitors.

2) Advanced knowledge: Advanced knowledge is what makes the company competitively viable. Such knowledge allows the company to differentiate its product from that of a competitor, arguably, through the application of superior knowledge in certain areas. Moreover, such knowledge allows the company to compete head on with its competitors in the same market and for the same set of customers.

3) Innovative knowledge: Innovative knowledge allows a company to lead its entire industry to an extent that clearly differentiates it from competition. Innovative knowledge also allows a company to change the rules of the game.

IASCO in the position of a large industrial unit in alloy steel industry is able to produce a wide range of alloy steel grades. Thus, IASCO is located between other similar competitors in Asia and Europe in terms of the variety of alloy steel products. In the internal market, each one of domestic manufacturers just is able to produce a small range of alloy products. So, they might not be able to compete with IASCO in that case. In terms of knowledge position, IASCO has the core knowledge for production of general alloy steels so that in recent years IASCO by producing special alloy steels, has been pioneer in compare with other internal and external companies. So, IASCO is also achieved to the advanced knowledge.

\section{Choose codification or personalization as the KM} focus.

As pointed before; two strategies exist for knowledge management: codification and personalization. Both of them are required in the right balance.

The right balance is determined by the company's objectives in pursuing knowledge management. In addition to balancing personalization and codification, the company must balance the level of exploration and exploitation that wants to engage. Exploration implies the intent of the company to develop knowledge that helps it to create new niches for its products and services. Exploitation implies the intent to focus on deriving financial and productivity gains from knowledge [5]. Table III compares these two choices of strategies for IASCO using some questions and scoring them, based on Tiwana's model. This can help the company to select both strategies but not with equal weight.

To determine the appropriate KM-ST by offered questions in Table III, the obtained average scores of codification and personalization indicate that the IASCO should direct 70 percent of its efforts toward codification and the remaining 30 percent toward personalization.

\section{E. Create a knowledge map for your industry and assess} your competition's learning capabilities.

The knowledge map provides a snapshot of where the company is at any given time relative to its competitors. Knowledge is not static. Hence, what is innovative knowledge today will become the core knowledge of tomorrow. The key lies in staying consistently ahead of the competition [5]. Fig. 3 and 4 shows a knowledge map in two situations for evaluating the knowledge of IASCO. To create knowledge map, each market player including IASCO must be categorized as an innovator, leader, capable competitor, straggler, or risky player. Then, IASCO's strengths and weaknesses on various facets of knowledge will be identified to see where IASCO has lagged or leaded with its competitors.

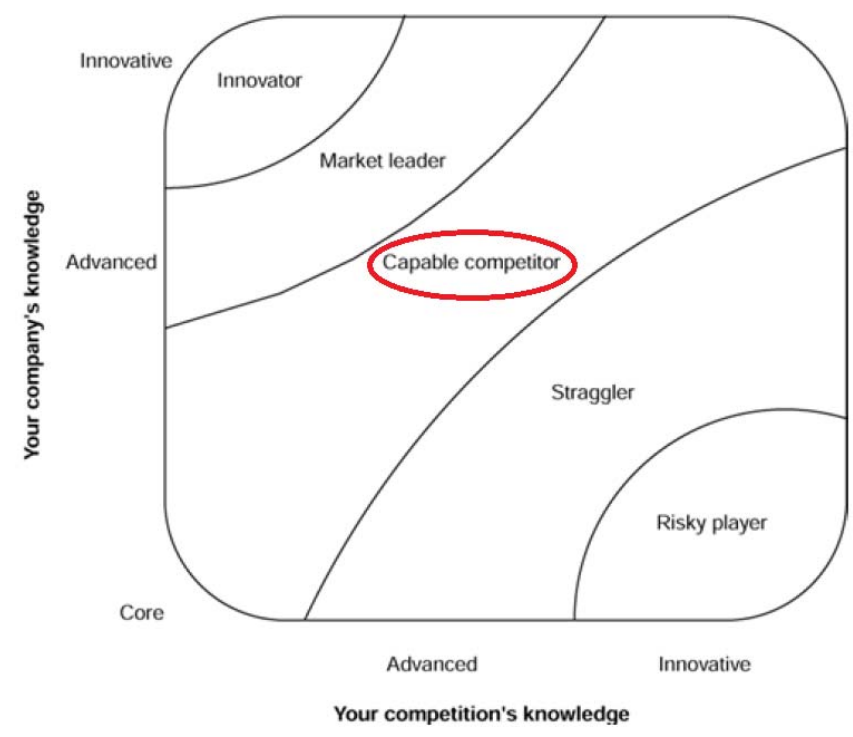

Fig. 3. Internal knowledge map for IASCO

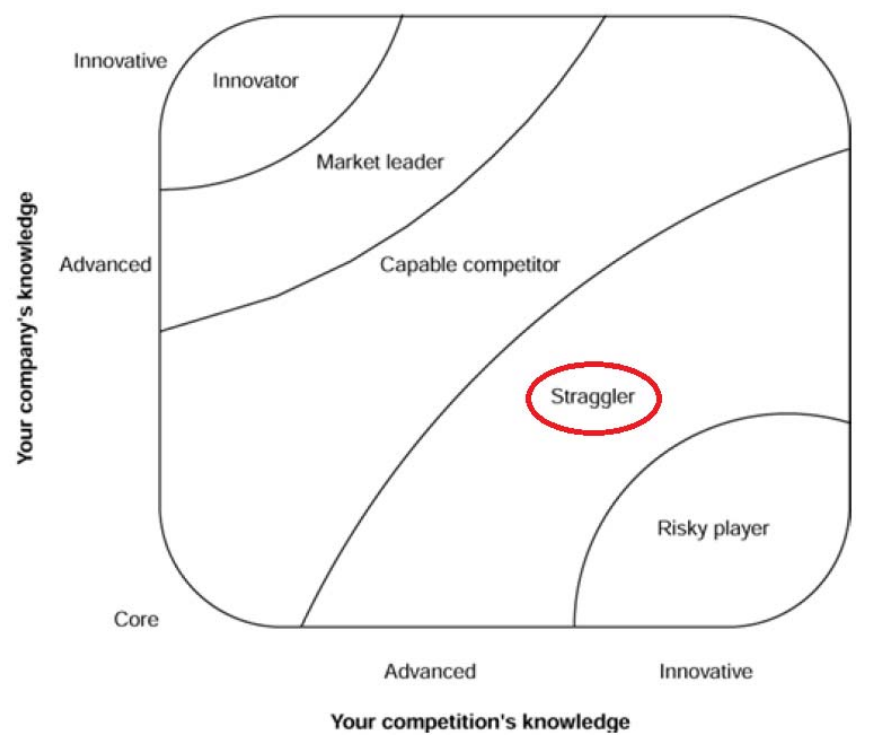

Fig. 4. External knowledge map for IASCO

Fig. 3 shows a capable competitor as the knowledge map of IASCO between its internal competitors. This means that 
the status of knowledge of IASCO against internal competitors such as Esfarayen steel company and Isfahan alloy steelcompany (IASC) is almost the same level in terms of technical knowledge of producing special alloys with high quality and reliability and low cost. On the other hand, as illustrated in Fig. 4, IASCO has a straggler player between its external competitors. It indicates that the foreign competitors such as Bohler of Austrian, BSW of Germany, Saudi Alhdyd and alloy steel of Turkey determine export market prices and have also obtained greater market share. For more export and earn more foreign markets, IASCO should raise production tonnage alloy steels in different grades.

TABLE III: COMPARISON OF CODIFICATION AND PERSONALIZATION KM-ST IN IASCO

\begin{tabular}{|c|c|c|c|c|}
\hline \multirow[t]{2}{*}{$\begin{array}{c}\text { Business Strategy } \\
\text { Question }\end{array}$} & \multicolumn{2}{|l|}{ Codification } & \multicolumn{2}{|l|}{ Personalization } \\
\hline & criterion & score & criterion & score \\
\hline $\begin{array}{l}\text { What type of business do you think } \\
\text { your company is in? }\end{array}$ & $\begin{array}{l}\text { Providing high-quality, reliable, fast, and } \\
\text { cost effective services. }\end{array}$ & 35 & $\begin{array}{l}\text { Providing creative, rigorous and highly } \\
\text { customized services and products. }\end{array}$ & 65 \\
\hline $\begin{array}{l}\text { How much old material, such as past } \\
\text { project data, existing documents, } \\
\text { and archived projects, do you reuse } \\
\text { as a part of new projects? }\end{array}$ & $\begin{array}{l}\text { You reuse portions of old documents to } \\
\text { create new ones. You use existing } \\
\text { products to create new ones. You know } \\
\text { that you need not begin from scratch to } \\
\text { deliver a new product or service. }\end{array}$ & 80 & $\begin{array}{l}\text { Every problem has a high chance of being a } \\
\text { "one-off" and unique problem. Although } \\
\text { cumulative learning is involved, highly } \\
\text { creative solutions are often called for. }\end{array}$ & 20 \\
\hline $\begin{array}{c}\text { What is the costing model used for } \\
\text { your company's products and } \\
\text { services? }\end{array}$ & Price-based competition. & 70 & $\begin{array}{l}\text { Expertise-based pricing; high prices are not } \\
\text { detrimental to your business; price-based } \\
\text { competition barely exists. }\end{array}$ & 30 \\
\hline $\begin{array}{c}\text { What are your firm's typical profit } \\
\text { margins? }\end{array}$ & $\begin{array}{l}\text { Very low profit margins; overall } \\
\text { revenues need to be maximized to } \\
\text { increase net profits. }\end{array}$ & 75 & Very high profit margins. & 25 \\
\hline $\begin{array}{l}\text { How best can you describe the role } \\
\text { that IT plays in your company's } \\
\text { work processes? }\end{array}$ & $\begin{array}{l}\text { IT is a primary enabler; the objective is to } \\
\text { connect people distributed across the } \\
\text { enterprise with codified knowledge } \\
\text { (such as reports, documentation, code, } \\
\text { etc.) that is in some reusable form. }\end{array}$ & 60 & $\begin{array}{l}\text { Storage and retrieval are not the primary } \\
\text { applications of IT; IT is considered a great } \\
\text { enabler for communications; applications } \\
\text { such as e-mail and video conferencing age } \\
\text { considered the most useful applications; } \\
\text { conversations, socialization, and exchange of } \\
\text { tacit knowledge are considered to be the } \\
\text { primary use of IT. }\end{array}$ & 40 \\
\hline What is your reward structure like? & $\begin{array}{l}\text { Employees are rewarded for using and } \\
\text { contributing to databases such as Notes } \\
\text { discussion databases. }\end{array}$ & 90 & $\begin{array}{l}\text { Employees are rewarded for directly sharing } \\
\text { their knowledge with colleagues and for } \\
\text { assisting colleagues in other locations/offices } \\
\text { with their problems. }\end{array}$ & 10 \\
\hline $\begin{array}{l}\text { How is knowledge exchanged and } \\
\text { transferred? }\end{array}$ & $\begin{array}{l}\text { Employees refer to a document or best } \\
\text { practices database that stores, distributes, } \\
\text { and collects codified knowledge. }\end{array}$ & 80 & $\begin{array}{l}\text { Knowledge is transferred person to person; } \\
\text { intrafirm networking is encouraged to enable } \\
\text { sharing of tacit knowledge, insight, } \\
\text { experience, and intuition. }\end{array}$ & 20 \\
\hline $\begin{array}{l}\text { Where do your company's } \\
\text { economies of scale lie? }\end{array}$ & $\begin{array}{l}\text { Economies of scale lie in the effective } \\
\text { reuse of existing knowledge and } \\
\text { experience and applying them to solve } \\
\text { new problems and complete new } \\
\text { projects. }\end{array}$ & 70 & $\begin{array}{l}\text { Economies rest in the sum total of expertise } \\
\text { available within the company; experts in } \\
\text { various areas of specialization are considered } \\
\text { indispensable. }\end{array}$ & 30 \\
\hline $\begin{array}{l}\text { What are your typical team structure } \\
\text { demographics? }\end{array}$ & $\begin{array}{c}\text { Large teams; most members are } \\
\text { junior-level employees; a few project } \\
\text { managers lead them. }\end{array}$ & 85 & $\begin{array}{c}\text { Junior employees are not an inordinate } \\
\text { proportion of a typical team's total } \\
\text { membership. }\end{array}$ & 15 \\
\hline $\begin{array}{l}\text { What company's services do your } \\
\text { company's services resemble? }\end{array}$ & $\begin{array}{l}\text { Organization is more attention to } \\
\text { production. Examples: Andersen } \\
\text { Consulting, The Gartner Group, Delphi } \\
\text { Consulting, ZDNET, Delta Airlines, } \\
\text { Oracle. }\end{array}$ & 90 & $\begin{array}{l}\text { Organization provides more consulting } \\
\text { services. Examples: Boston Consulting } \\
\text { Group, McKinsey and Company, Rand } \\
\text { Corporation. }\end{array}$ & 10 \\
\hline $\begin{array}{l}\text { What company's products do your } \\
\text { company's products resemble? }\end{array}$ & $\begin{array}{c}\text { Products based on common needs are } \\
\text { made. Examples: } \\
\text { Pizza Hut, Dell Computer, Gateway, } \\
\text { Microsoft, SAP, People Soft, Baan, } \\
\text { America Online, Bell South, Air Touch } \\
\text { Cellular, Lotus, SAS Institute, IBM, } \\
\text { Hewlett-Packard }\end{array}$ & 35 & $\begin{array}{l}\text { Products based on customer orders are made. } \\
\text { Examples: A custom car or bicycle } \\
\text { manufacturer, Boeing, a contract research } \\
\text { firm, a private investigator. }\end{array}$ & 65 \\
\hline \multicolumn{2}{|c|}{ The average score for IASCO: } & 70 & Personalization $=$ & 30 \\
\hline
\end{tabular}

\section{DisCUSSION AND CONCLUSION}

In this paper, how to get the proper knowledge management strategy are described. Moreover the link between business strategy and knowledge management strategy is also discussed. On the other hand, it is shown that how high-level business strategy can be translated into pragmatic and doable goals can drive knowledge management strategy. Indeed, how knowledge maps can translate strategic vision into action and further translate this into a supporting knowledge management system design is examined. The Tiwana's model (based on Michael Zack) is 
applied to develop a knowledge management strategy that truly delivers results in the company. IASCO is selected in advanced as a real case to determine a proper KM-ST based on the steps of Tiwana' model. Connecting between the business strategy and the level of current knowledge of IASCO can help managers to make a better decision for the required level of knowledge of company in future. To determine the KM-ST for the IASCO, two famous strategies including codification and personalization are considered. Codification strategy attempts to codify knowledge so that its goal is transforming tacit knowledge to explicit knowledge. But personalization strategy mainly intends to share the knowledge of company through direct person-to-person contacts. Based on Tiwana's model both strategies are required in proper balance in company. Using some useful questions, directed the company to select $70 \%$ codification strategy and only $30 \%$ personalization strategy. This means, managers in IASCO should pay greater attention to codify knowledge andcodification activates must be considered as primary KM-ST of IASCO, comparing the exchanging knowledge between persons-to-person that should be considered in the second stage. Thus, based on Tiwana's model, strategy $70 \%$ to $30 \%$ can help the IASCO to create the competitive advantage and reach to the goals, sooner.

\section{REFERENCES}

[1] A. Carneiro, "How does knowledge management influence innovation and competitiveness?” J. Knowledge Manage., vol. 4, pp. 87-98, 2000.

[2] F. Gao, M. Li and S. Clarke, "Knowledge, management, and knowledge management in business operations," J. Knowledge Manage., vol. 12, pp. 3-17, 2008.

[3] R. Shankar, M. D. Singh, A. Gupta and R. Narain, "Strategic planning for knowledge management implementation in engineering firms," Work Study, vol. 52, pp. 190-200, 2003.

[4] I. R. Edvardsson, "HRM and knowledge management," Employee Relations, vol. 30, pp. 553-561, 2008.

[5] A. Tiwana, "Knowledge Management Toolkit, The: Orchestrating IT, Strategy, and Knowledge Platforms," 2nd ed., Upper Saddle River: Prentice Hall, 2003.
[6] C. A. Montgomery and M. E. Porter, "Strategy: Seeking and Securing Competitive Advantage," Harvard Business School Press, Boston, 1991.

[7] P. Bierly, and A. Chakrabarti "Generic Knowledge Strategies in the U.S. Pharmaceutical Industry," Strategic Manage. J., vol. 17, pp. 123-135, 1996.

[8] A. Abdollahi, A. Rezaeian and M. Mohseni, "Knowledge Strategy: Linking Knowledge Resources to Competitive Strategy," World Appl. Sci. J., vol. 4, pp. 08-11, 2008.

[9] B. Choi, S. K. Poon and J. G. Davis, "Effects of Knowledge Management Strategy on Organizational Performance: A Complementarity Theory-Based Approach," Omega, vol. 36, pp. 235-251, 2008.

[10] M. T. Hansen, N. Nohria and T. Tierney, "What's your Strategy for Managing Knowledge?” Harvard Business Review, March-April, pp. 106-16, 1999.

[11] S. R. Clegg and T. Clarke, "Intelligent Organizations?" in: S.E. Clegg, E. Ibarra-Colado, L. Bueono-Rodriquez, Eds. Global Management, Universal Theories and Local Realities, Sage, London, 1999, pp. 177-201.

[12] M. Gloet and M. Berrell, "The Dual Paradigm Nature of Knowledge Management: Implications for Achieving Quality Outcomes in Human Resource Management," J. Knowledge Manage. vol. 7, pp. 78-89, 2003.

[13] M. H. Zack, "Developing a Knowledge Strategy," California Management Review. Vol. 41, pp. 125-145, 1999.

[14] J. Swan, S. Newell and M. Robertson, "Limits of IT-Driven Knowledge Management for Interactive Innovation Processes: Towards a Community-Based Approach," in: B. Schriver, R. H. Sprague, Eds. Hawaii international conference on system sciences. C. A. Los Alamitos, H. I. Maui, IEEE Computer Society Press, 2000.

[15] M. Schulz and L. A. Jobe, "Codification and Tactiness as Knowledge Management Strategies: an Empirical Exploration," J. High Tech. Manage. Res. vol. 12, pp. 139-165, 2001.

[16] B. Choi and H. Lee, "An Empirical Investigation of KM Styles and their Effect on Corporate Performance," Inform. Manage., vol. 40, pp. 403-417, 2003.

[17] H. Keskin, "The Relationships between Explicit and Tacit Oriented KM Strategy, and Firm Performance," J. America. Acad. Bus. Cambridge. vol. 7, pp.169-175, 2005.

[18] D. C. Pai, "Knowledge Strategies in Taiwan's IC Design Firms," J. America. Acad. Bus. Cambridge, vol. 7, pp. 73-77, 2005.

[19] H. Koo, K.Y. Chau, L.C. Koo, S. Liu and S. C. Tsui, "A Structured SWOT Approach to Develop Strategies for the Government of Macau, SAR,” J. Strategy Manage., vol. 4, pp. 62-81, 2011.

[20] M. M. Helms and J. Nixon, "Exploring SWOT Analysis - where are we now? A review of academic research from the last decade," J. Strategy Manage, vol. 3, pp. 215-251, 2010. 